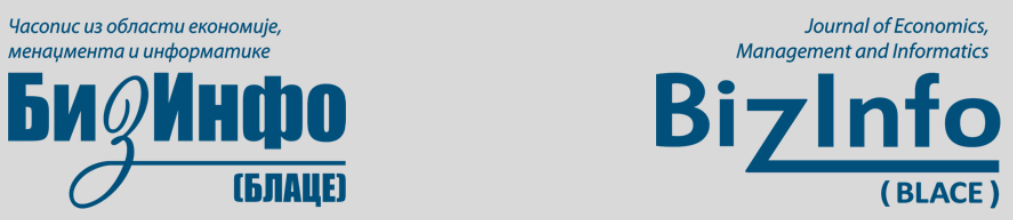

Оригиналан научни рад/ Original scientific paper

УДК/UDC: $338.48-6: 7 / 8$

004.738.5:[338.482:159.9

https://doi.org/10.5937/bizinfo2002001D

\title{
Influence of internet content on tourists decision to visit a cultural tourism destination ${ }^{1}$
}

\section{Uticaj internet sadržaja na odluku turiste o poseti destinacije kulturnog turizma}

\author{
Sandra Dramićanin ${ }^{\mathrm{a} *}$, Branislav Sančanin ${ }^{\mathrm{b}}$ \\ ${ }^{a}$ University of Kragujevac, Faculty of Hotel Management and Tourism in Vrnjačka Banja, \\ Serbia \\ ${ }^{\mathrm{b}}$ Nikola Tesla University, Union- Faculty of Management in Sremski Karlovci, Serbia
}

\begin{abstract}
Culture is an important element of a destination tourist product, and tourism is an apparatus for meeting the various cultural needs of tourists. The relationship between culture and tourism contributes to the support of the cultural sector, innovation, creativity, the image of the destination and the social connection between tourists and the local population. Nowadays, it is impossible to imagine the functioning of tourism without the Internet. Presenting the cultural offer of the destination via the Internet is a great challenge and requires exceptional commitment. The subject of research of this paper is the influence of Internet content on the decision of the tourists about the destination of cultural tourism they will choose. The aim of the research is to influence the internet content on tourists related to the cultural tourism of the destination and the possibility of attracting tourists to visit the destination based on the reviewed Internet content. The research involved 165 respondents who visited one of the cultural tourism destinations from the territory of the Republic of Serbia. The results of the research show that a higher level of quality of Internet content has a positive effect on tourists choosing a certain cultural tourism destination for travel and that Internet content in terms of information efficiency, interactivity and practicality has a significant positive impact on tourists' intentions to visit cultural tourism destination.
\end{abstract}

Keywords: cultural tourism, internet content, destination

Sažetak: Kultura predstavlja važan element turističkog proizvoda jedne destinacije, a turizam aparat podmirivanja različitih kulturnih potreba turista. Veza kulture i turizma doprinosi

\footnotetext{
${ }^{1}$ Paper presented at Scientific conference "The impact of traditional and digital media on the promotion and sustainable development of cultural heritage" held in Sremski Karlovci, Serbia

${ }^{*}$ Corresponding author.

E-mail address: sandradramicanin @ hotmail.com
}

This is an open access paper under the license (c) (1) (8) 
podršci sektora kulture, inovativnosti, kreativnosti, imidžu destinacije i socijalnoj povezanosti između turista i lokalnog stanovništva. U današnje vreme nemoguće je zamisliti funkcionisanje turizma bez interneta. Predstavljanje kulturne ponude destinacije putem interneta je veliki izazov $i$ zahteva izuzetnu posvećenost. Predmet istraživanja ovog rada čini uticaj internet sadržaja na odluku turiste o destinaciji kulturnog turizma koju će izabrati. Cilj istraživanja je uticaj internet sadržaja vezanog za kulturni turizam destinacije na turiste $i$ mogućnosti privlačenja turista da posete destinaciju na osnovu pregledanog internet sadržaja. U istraživanju je učestvovalo 165 ispitanika koji su posetili neku od destinacija koje se bave kulturnim turizmom na teritoriji Republike Srbije. Rezultati istraživanja pokazuju da viši nivo kvaliteta internet sadržaja pozitivno utiče da turista odabere određenu destinaciju kulturnog turizma za putovanje i da internet sadržaj u smislu efikasnosti informacija, interaktivnosti $i$ praktičnosti ima značajno pozitivan uticaj na namere turista da posete destinaciju kulturnog turizma.

Ključne reči: kulturni turizam, internet sadržaj, destinacija

\section{Introduction}

Tourism is an activity that relies heavily on information, so the development of destinations increasingly depends on the ability to monitor and adapt to modern trends and rapid adaptation and ability to manage new technologies. Internet content provides tourism with various marketing benefits and targeted business that significantly influences the decisions of tourists. Modern tourists start their journey by opening websites related to attractive places and potential destinations. By studying their content, they get information about the destination, accommodation capacities, and the type of transport, attractions and places that should be visited during the trip in order to complete the experience.

The basis of cultural tourism is to meet the needs of tourists to visit the cultural site, participate in cultural activities and experience an authentic and unforgettable experience. The wide range of different activities of this type of tourism makes tourists feel welcome and desirable by local communities in every destination.

The popularity of cultural tourism is increasing and its growth rates exceed the world average. Personalized content, short videos showing the reality of cultural destinations, interactive footage and virtual reality help. All of them significantly change the current understanding of tourism. From year to year, the number of independent internet sites related to cultural tourism is increasing, which provide advice to tourists, before and during the trip, with the possibility of leaving information about experiences from the destination. Tourists use maps and promotional publications to collect information about specific cultural locations, so internet content is becoming more quality, more visual and more attractive. However, tourists do not only want to collect information, but also want to leave their experiences from cultural destinations in the form of blogs, vlogs and other types of short videos, observations and comments.

By analyzing Internet content and trends, market segmentation, tracking the wishes and needs of tourists (new generations of tourists are closely linked to technology and the Internet), as well as understanding what information is crucial for tourists (to create an effective marketing tool), with continuous comparison with the competition and 
analyzing their business steps, companies engaged in cultural tourism, as well as entire cultural tourism destinations, can improve their position on the world tourist map and determine future directions of growth and development. Development and improvement of the quality of internet content dealing with cultural tourism and cultural tourism destinations is the key to differentiating the destination in relation to competitors.

\section{Cultural tourism}

Culture is an essential aspect of social existence and development. Various inventions, preservation and promotion of centuries-old cultural heritage are irreplaceable catalysts for the development of the destination (Sančanin \& Dramićanin, 2019). Cultural tourism means the movement of people caused by cultural attractions, with the intention of gathering new information and experiences to meet their cultural needs (Richards, 1999), for artistic and cultural tours, trips to festivals and other cultural events, visiting monuments and historical sites, traveling for art or pilgrimage (WTO, 2019). Cultural tourism is recognized as a sustainable form of tourism that helps in the regeneration of urban areas, preservation and promotion of national cultural heritage and traditions, in ensuring a better standard of the environment in which it develops (Dumon et al., 2007). Cultural tourism plays a major role in overall tourism trends. It helps to define the cultural heritage and cultural tradition of a tourist destination. Cultural heritage is very important because it can attract tourists from different cultures and religions (Munsters, 2004). Through visits to tourist destinations, cultural tourists feel and see cultural riches through sightseeing of architectural buildings, museums, historical cities that exude a monumental and traditional spirit (Russo, 2002).

Different lifestyles, needs, and habits produce different cultural styles and methods of satisfying them (Leask, 2010). The primary need to visit a cultural destination satisfies the tourists' need to participate in the cultural life of the locality by visiting exhibitions, festivals, concerts, museums, monuments and historical sites (Richards, 2005). For specialized cultural tourists, culture is of primary importance, and cultural activities have the strongest influence on the choice of destination. The purpose of their trip is to visit a destination, in need of understanding the culture of the area or locality or searching for a certain kind of art. Tourists are attracted to cultural tourism destinations by material and intangible attractions, while tourists after staying at the destination are left with only intangible experience (Angley et al., 2014).

Cultural tourism attracts tourists with its sights and manifestations, spirit and vitality and consequently brings many benefits to destinations: improving the appearance and image of the city, increasing the city's detectable on the world cultural map, improving cultural development, development of cultural (manifestation) tourism, cultural regeneration (Todorović, 2008). Elements of acquaintance and discovering the city have an extraordinary charm for visitors. The novelties, experiences and adventure that modern tourists are looking for can be found in cultural tourism destinations. 


\section{Decision making process}

The travel decision-making process is much more complex than the material goods decision-making process (Park et al., 2013), so there are a number of theoretical models about the travel destination decision-making process (Kotler \& Keller, 2017; Kardes et al., 2011). Choosing the most suitable destination, way of traveling and accommodation is a process that consumes time and effort (Hsu et al., 2012). As people increasingly focus on the quality of the tourism experience, the demand for open information in tourism becomes intense (Wu et al., 2014). The decision to go on a trip stems from the tourist's desire to visit a certain destination, vacation, adventure or leisure (Živković \& Brdar, 2018). Also, many tourists decide to travel, motivated by the desire to get to know the cultural and historical heritage of a place, region or country (Perić et al., 2020). They emphasize their interest in the different cultural content, crafts, rituals, gastronomy, and the interpretation of the nature and universe (Sančanin et al., 2019). The process of deciding on a travel destination is shown in Figure 1.

Figure 1. The travel destination decision process

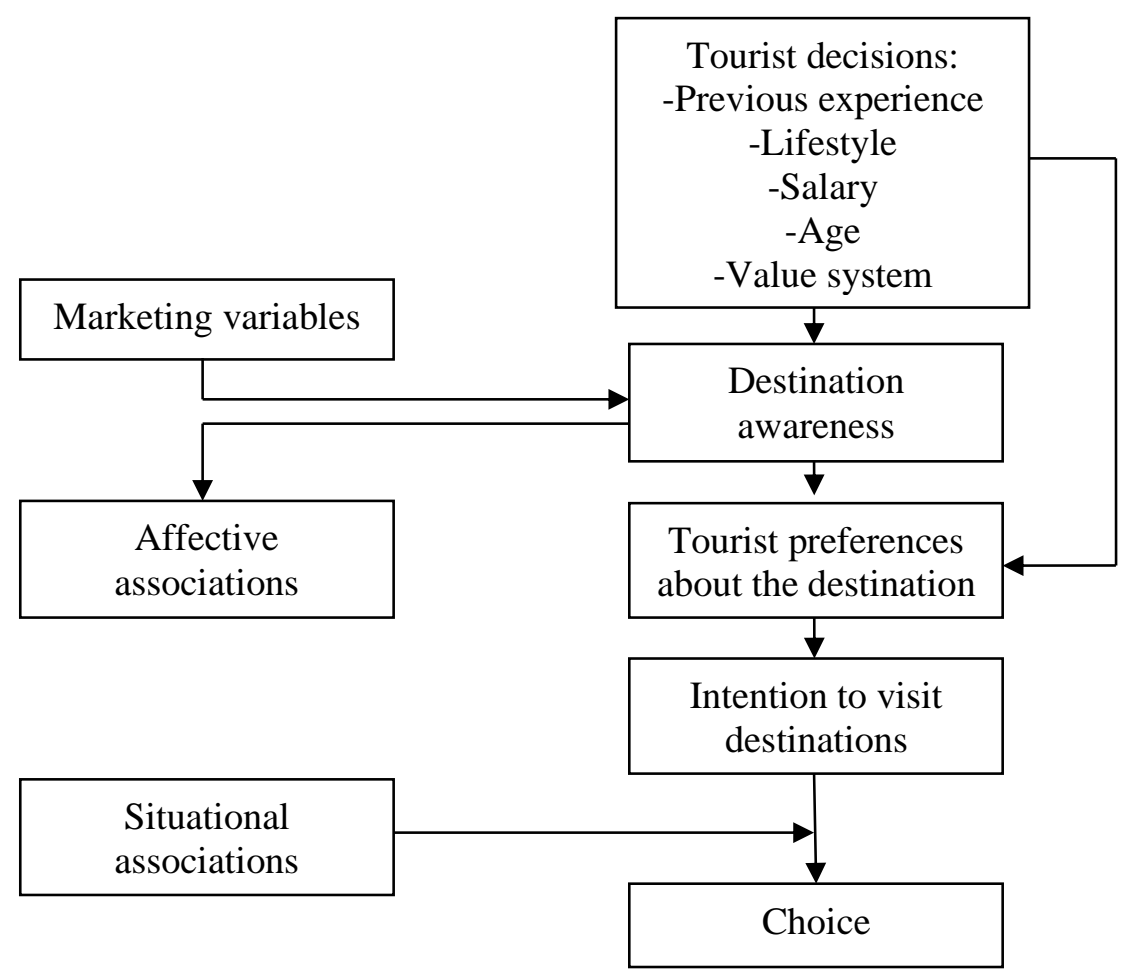

Source: Woodside, A., \& Lysonski, S. (1989). A General Model of Traveler Destination Choice. Journal of Travel Research, 27, p. 11.

Although motivation drives to action and leads to the satisfaction of needs, a more precise filter of choice is the preference of the tourist. Preferences are more specific 
than motives and they are shown through where the tourists travel and what they are doing at the destination (Smith et al., 2010). It is extremely important to recognize micro moments in the decision-making process (Yoo et al., 2010). The first moment is the dreaming phase when the tourist chooses a holiday destination, followed by planning: the tourist knows the destination, but should choose a hotel and other activities at the destination, then comes comparing prices on different sites and booking accommodation and finally, local search at the destination: where to go, what to see and experience, who to contact for the local tour (Lawet al., 2009).

Nowadays, most tourists chose Internet in search of information that helps them make a decision about a travel destination (Petan, 2008). Online reviews are based on tourist profiles and their established preferences and they are an integral part of formulating preferences and impacts on future bookings (Baka, 2016). Research has shown that about $95 \%$ of tourists in the world are informed via the Internet, about $93 \%$ of tourists visit websites in order to search for tourist destinations (Mamaghani, 2009). In order to minimize uncertainty when searching online, tourists increasingly rely on the recommendations of other users to make a safer decision about which destination to travel to (Thao \& Swierczek, 2008). According to the results of a survey conducted by Liu \& Park (2015), 83\% of tourists use the Internet in the travel planning phase, before the final decision is made. In the tourist context, the recommendations of tourists through Tripadvisor, Booking.com, influence the decisions of other travelers on various aspects of their travels, e.g. choice of tourist destination, accommodation and attractions to visit (Pantano et al., 2017). Regardless of the fact that some researchers have indicated that many reviews are fake or that they are overly positive or negative, tourists perceive online reviews as more reliable than the content provided by the official website of the destination (Fotis et al., 2012).

Numerous internet tools have enabled tourists to make a faster decision about their travel destination, by facilitating access to information and booking accommodation, airline tickets and other tourist services (De Carlos et al., 2015). There has also been an increasing use of a variety of SoLoMo (Social-Location-Mobile based) applications that have made the decision-making process easier for tourists (Kim \& Connolly, 2012). Clients can choose the attributes and mode of travel that suit them, and platforms (applications) will automatically form a route based on the entered criteria and display appropriate information about potential travel destinations, thus helping tourists and speeding up travel destination decisions.

\section{The impact of internet content}

The development of information technologies has an exceptional impact on the everyday life of modern man. It is thanks to this that connecting people has become simple and fast, and information is easily available in large quantities. At the same time, the exchange of information between offer and demand in tourism has begun to take place interactively in real time (Chung \& Buhalis, 2008). The Internet with multimedia content provides the possibility of coverage worldwide and an important means of promotion and distribution of tourism products or services (Rodriguez Vazquez et al., 2015). 
The wealth of information available on the Internet allows tourists to search for the most diverse offers of tourist destinations on their own (Eskelsen et al., 2009). While the Internet, in itself, with almost free access and standardized technical knowledge, cannot be considered a source of competitive advantage, what significantly affects its acquisition is online visibility, ie information that is at the top of the list of results on search engines when searching for tourist content. (Smithson et al., 2011).

The essence of using internet content is to establish relationships and communication between tourists who have used the services and products of the destination and potential tourists. Internet sites such as Booking, Tripadvisor, Expedia, Trivago, Airbnb are one of the most visited sites where tourists search for information about potential destinations. At the same time, they collect information from Facebook, Twitter, Instagram, Google + , Pinterest accounts of various users by following travel blogs. The Internet as a popular source for collecting information about destinations, activities, natural and anthropogenic attractions, hotels, restaurants, cafes, provides an opportunity to influence a potential tourist positively or negatively (Volo, 2010). The image of the destination and the experience of travelers who have visited the destination play a key role in deciding where to travel (Li \& Wang, 2011; Choi et al., 2007). Users of Internet content are no longer passive recipients of information about destinations; they can now communicate with the authors of that information and with other users (Cao et al., 2017).

Understanding the benefits of quality and adequate content is one of the biggest challenges destinations face. Internet content creators need to understand the effectiveness of social networking in order to gain a favorable marketing position and facilitate communication with tourists. If the internet content is inadequate, inappropriate and incomplete or it has inaccurate information, tourists will avoid it (Milano et al., 2011). In order for internet content to have an effect, it is necessary that $25 \%-50 \%$ of full-time employees effectively lead and manage an internet content campaign that represents tourism company or destination (Turner, 2012).

The rapid evolution of information technology motivates tourists to review the entire travel process before making travel decisions, and tourists who have already been on such a trip to share their impressions and experiences (Kipper \& Rampolla, 2013). Online platforms that provide information on places of interest for sightseeing, accommodation, restaurants, traffic, entertainment and shopping must maintain up-todate and accurate information on popular tourist destinations and provide useful tourist information that is in line with tourists' preferences (Xiaolong et al., 2016). For example, a system called PlanTour uses an automated planning approach to generate a multi-day plan with the most relevant points of interest in a destination being visited. The system collects information about users and points of interest, and then uses an automated planner that forms quality tourism plans based on user ratings on social networks. An intelligent system is used that combines the generated knowledge with efficient automated techniques (Cenamor et al., 2017). Specialized blogs provide free web spaces to businesses in order to place travel offers and allow online visitors to share their unique experiences and experiences from their travels. Blogs are part of an online community, made up of groups of visitors who share common interests and share experiences through forums or chat (Sigala et al., 2007). 
Internet content has a specific characteristic, and that is the possibility of constant change and adjustment, so search engine optimization is a necessary tool that helps improve the visibility of a page of a tourist destination (Terrelonge, 2011). In that way, the destination can attract potential tourists to visit it. The global tourism industry is moving towards maximum use of internet content to promote its offer. The networking of information via the Internet is growing rapidly, so it is necessary for tourist destinations to adapt in order to succeed.

\section{Methodology}

\section{Questionnaire design and preliminary testing}

For the needs of this research, a questionnaire consists two parts. The first part includes demographic characteristics, number of trips to cultural tourism destinations, source of information about them and frequency of use and type of internet content related to cultural tourism. The second part of the questionnaire is the main part of the entire research. The questionnaire contains questions related to internet content linked to cultural tourism and tourists' decisions about travel destinations; it is adapted based on the existing questionnaire constructed by Cao et al. (2017). Four items measure the intention of tourists to make a decision regarding the destination of the trip, and 25 items measure the characteristics of internet content related to cultural tourism. These items are divided into 8 subcategories: participation (3 questions), interactivity (3 questions), divisibility (3 questions), connectivity (3 questions), quality (3 questions), convenience (3 questions), information transparency (3 questions) and information effectiveness (4 questions). Respondents expressed their opinion with a score of 1-5, where 1- is absolute disagreement and 5- is absolute agreement. They filled in the questionnaire online, and only condition was that they visited one of the cultural tourism destinations in Republic of Serbia.

Preliminary testing was conducted in 2018, on a sample of 92 respondents (the research was conducted partly online and partly in personal contact with respondents), of which 85 were valid, so the valid response rate is $92.39 \%$. The results of the reliability testing of the SPSS 21 program show that the entire questionnaire has high reliability, the Cronbach Alpha coefficient is 0.922. After that, the final questionnaire was formatted in electronic form.

\section{Sample selection and data collection}

The research was conducted during July and August 2020. Total of 200 respondents who visited a cultural tourism destination in Serbia were asked to fill out a questionnaire. The questionnaire was completed by 171 respondents $(85.5 \%)$. Out of that number 165 questionnaires were valid, which is $96.49 \%$. Demographic characteristics of the respondents are shown in Table 1. 
Table 1. Demographic characteristics of respondents

\begin{tabular}{lcc}
\hline & \multicolumn{2}{c}{ Frequency $(N=165)$} \\
\cline { 2 - 3 } Gender & $N$ & $\%$ \\
$\quad$ Male & 56 & 33.9 \\
Female & 109 & 66.1 \\
Age & & \\
$18-20$ & 9 & 5.5 \\
$21-30$ & 64 & 38.8 \\
$31-40$ & 26 & 15.7 \\
$41-50$ & 34 & 20.6 \\
$51-60$ & 18 & 10.9 \\
More then 60 & 14 & 8.5 \\
Education & & \\
High school & 40 & 24.3 \\
College & 22 & 13.3 \\
University degree & 65 & 39.4 \\
Master & 35 & 21.2 \\
PhD & 3 & 1.8 \\
\hline
\end{tabular}

Source: Author's calculation

The number of trips to cultural tourism destinations, the source of destination information and type and frequency Internet content use are in Table 2.

Table 2. Number of trips, source of information and frequency of internet content use

\begin{tabular}{lcc}
\hline & \multicolumn{2}{c}{ Frequency $(N=165)$} \\
\cline { 2 - 3 } & $N$ & $\%$ \\
\hline Number of trips cultural tourism destination per year & 72 & 43.6 \\
Once & 75 & 45.5 \\
$2-5$ & 12 & 7.3 \\
More then 5 & 6 & 3.6 \\
Never & & \\
Information source of cultural tourism destinations & 23 & 13.9 \\
Recommendation of friends, acquaintances and relatives & 102 & 61.8 \\
Internet (sites, social networks, blogs) & 23 & 13.9 \\
Travel agency and tour operator & 17 & 10.3 \\
Brochures and booklet & & \\
Frequency of using internet content related to cultural & & \\
destinations & 86 & 52.1 \\
Once a day & 42 & 25.5 \\
Once a week & 23 & 13.9 \\
Once a month & 9 & 5.5 \\
Several times a year & 5 & 3.0 \\
Never & & \\
Type of internet content that tourists search for & 37 & 22.4 \\
Personal experience of previous passengers & 21 & 12.7 \\
Price information & 22 & 13.3 \\
Tourist guides and maps & 27 & 16.4 \\
Important sites to visit &
\end{tabular}


Accommodation 31

Surrounding places and traffic information

Source: Author's calculation

\section{Research results}

The results of the correlation analysis between the tourist's decision on the travel destination and the 8 factors that represent the characteristics of Internet content can be found in Table 3. The tourist's decision on the travel destination and eight Internet content factors have positive correlations $(\mathrm{r}<0.01)$ : quality $(\mathrm{r}=0.673)$, information effectiveness ( $\mathrm{r}=0.603)$, interactivity $(\mathrm{r}=0.595)$, convenience $(\mathrm{r}=0.565)$, participation $(\mathrm{r}=0.532)$, divisibility $(\mathrm{r}=0.478)$, connectivity $(\mathrm{r}=0.431)$ and information transparency $(\mathrm{r}=0.398)$.

Table 3. Results of the correlation analysis

\begin{tabular}{|c|c|c|c|c|c|c|c|c|c|}
\hline & 1 & 2 & 3 & 4 & 5 & 6 & 7 & 8 & 9 \\
\hline $\begin{array}{l}\text { Tourists' } \\
\text { decision of travel } \\
\text { destination }\end{array}$ & 1 & & & & & & & & \\
\hline Participation & 0.532 & 1 & & & & & & & \\
\hline Interactivity & 0.595 & 0.482 & 1 & & & & & & \\
\hline Divisibility & 0.478 & 0.303 & 0.436 & 1 & & & & & \\
\hline Connectivity & 0.431 & 0.317 & 0.451 & 0.432 & 1 & & & & \\
\hline Quality & 0.673 & 0.254 & 0.444 & 0.440 & 0.505 & 1 & & & \\
\hline Convenience & 0.565 & 0.331 & 0.399 & 0.361 & 0.434 & 0.458 & 1 & & \\
\hline $\begin{array}{l}\text { Information } \\
\text { transparency }\end{array}$ & 0.398 & 0.323 & 0.405 & 0.332 & 0.521 & 0.372 & 0.410 & 1 & \\
\hline $\begin{array}{l}\text { Information } \\
\text { effectiveness }\end{array}$ & 0.603 & 0.404 & 0.502 & 0.430 & 0.446 & 0.531 & 0.492 & 0.399 & 1 \\
\hline
\end{tabular}

Source: Author's calculation

In order to further analyze the relationship between the characteristics of Internet content and the tourist's decision of travel destination, multiple regression analysis was used, where 8 characteristics of Internet content represent independent variables, and the tourist's decision a dependent variable. Table 4 shows the results of the regression analysis.

Table 4. Regression analysis

\begin{tabular}{lcccc}
\hline & $\beta$ & $\mathrm{R}$ & Adjust $^{2}$ & $p$ \\
\hline Quality & 0.288 & 0.741 & 0.539 & 0.000 \\
Interactivity & 0.209 & 0.723 & 0.515 & 0.000 \\
Information & 0.254 & 0.736 & 0.535 & 0.005 \\
effectiveness & 0.123 & 0.712 & 0.498 & 0.010 \\
Convenience & 0.085 & 0.698 & 0.465 & 0.000 \\
Participation & &
\end{tabular}

Source: Author's calculation 
The results show that 5 out of 8 characteristics have a positive and significant connection, which means that these 5 characteristics (quality, interactivity, information effectiveness, participation and convenience) have a positive effect on the tourist's decision about the travel destination, while three characteristics (divisibility, connectivity, information transparency) the regression coefficient is not significant.

\section{Discussion}

Internet content is playing an increasingly important role as a source of information for tourists (Xiang, Ulrike, 2010). Sharing experiences through online content emerges as a valuable interaction of social and emotional support and as an important source of information for holiday decisions (Munar, Steen-Jacobsen, 2014). Increasing reliance on the Internet as a source of information when making decisions about tourist trips, creates the need to research the information found on the Internet and their characteristics (Sparks \& Browning, 2011).

The Internet contents of tourist destinations differ significantly in terms of language characteristics, semantic characteristics, feelings, ratings, usefulness, as well as the relationship between these characteristics (Xiang et al., 2017) and affect tourists in different ways when deciding on a cultural tourism destination.

Negative comments, negative characteristics and unreliability of internet content make the complete impression of the destination negative, while positive ones stimulate the need and increase the intention of tourists to book a trip (Torres, 2017). One of the growing uses and benefits of internet content is reflected in the engagement of actual and potential visitors (Romolini et al., 2020). Engaging clients to promote a particular destination facilitates the impact of internet content features and attracts tourists (Harrigan et al., 2017). Internet generated by tourists is important new information mediums for other, potential tourists throughout the shopping life cycle, transforming the way visitors evaluate, choose cultural tourism destinations and share experiences about this type of tourism (Yue et al., 2017).

Internet content related to cultural tourism has played a key role in destination marketing, and their rapid spread has transformed the way information is accessed and how it affects tourists (Pantano \& Di Pietro, 2013). Tourists can access this information to facilitate the decision-making process. This information is freely available online and generates open data (Pantano et al., 2017). Internet content expands its capabilities by providing a diverse portfolio of embedded applications to meet user needs for new experiences (Tung et al., 2014), including comments on past experiences and recommendations for future bookings (Turban et al., 2015). Internet content is not only used as an advertising tool, but is also used for digital marketing, sales promotion, and even in personal sales (Radosavljević \& Ljubisavljević, 2020). Such characteristics of internet content positively influence the decision of the tourist about the travel destination (Pirroli, 2016).

The impact of the Internet and its content on tourist behavior and decision was investigated by Tierney (2000) and Buhalis \&Licata (2002) who came to the same conclusion: the characteristics of Internet content have a significant impact on tourist 
behavior and decisions. Valdez (2012) in his research examines the influence of Hypertext as an element of internet content on the decision of tourists and comes to the conclusion that there is a positive connection. Yu (2013) lists three essential characteristics of internet content: interactive, multimedia and hypertext, which distinguishes the concept of internet content from traditional and new media and contributes to easier navigation of tourists and faster finding of necessary information. In their study, Jiao et al. (2013) state that the characteristics of internet content such as quality, efficiency and transparency have the greatest impact on tourists, and Cao et al. (2017) came to results that are consistent with the results of this paper.

\section{Conclusion}

The large amount of information available through the Internet content, allows tourists to search for interesting destinations of cultural tourism, interesting places, affordable prices. Of great importance to tourists is the experience shared on the Internet by travelers who have already visited a certain destination of cultural tourism, stayed in a hotel, visited a museum or other cultural site or used the services of a tourist company. Due to the daily progress of the Internet, there is a change in the form and characteristics of its content, creative processes, mechanisms of distribution and promotion and patterns of sharing that Internet content. Internet content is used to find a large number of accurate, precise, updated information about one place. So that the tourist, even before the trip, knows what can be expected of him at the destination and to make a decision about trip destination with ease based on the information obtained. However, given the novelty of the topic, it seems that the literature is limited and this paper suggests the need for a deeper study of the use of Internet content in cultural tourism, in order to attract more tourists.

Nowadays, companies dealing with cultural tourism should pay attention to what information technology is and what are its characteristics that will attract as many tourists as possible, which applications should be used and what opportunities to offer to potential visitors. Cultural tourism destinations should first explore the needs of tourists and what kind of experience they want to experience, and then deliver the technology that will best fulfill their desires, while facilitating the process of making

\section{References}

Angley, D., O'Byrne-Prior, J., \& O'Connor, N. (2014). Visitor Attractions: The Future of Social Media in Heritage, Urban and Natural Tourism. International Hospitality and Tourism Student Journal, 6(4), 326-340.

Baka, V. (2016). The becoming of user-generated reviews: Looking at the past to understand the future of managing reputation in the travel sector. Tourism Management, 53, 148-162. https://doi.org/10.1016/j.tourman.2015.09.004

Buhalis, D., \& Licata, M. C. (2002). The future e-tourism intermediaries. Tourism Management, 23(3), 207-220. https://doi.org/10.1016/S0261-5177(01)00085-1

Cao, Q., Yu, B., \& Tian, T. X. X. (2017). The Effect of Social Media on Tourism Consumer Adoption Intention: Evidence from Urumqi. Journal of Accounting \& Marketing, 6(1), 219-229. https://doi.org/10.4172/2168-9601.1000219 
Cenamor, I., De la Rosa, T., Nunez, S., \& Borrajo, D. (2017). Planning for Tourism Routes Using Social Networks. Expert Systems with Applications, 69, 1-9. https://doi.org/10.1016/j.eswa.2016.10.030

Choi, S., Lehto, X. Y., \& Morrison, A. M. (2007). Destination image representation on the web: content analysis of Macau travel related websites. Tourism Management, 28, 118-129. https://doi.org/10.1016/j.tourman.2006.03.002

Chung, Y., \& Buhalis, D. (2008). Information Needs in Online Social Networks. Information Technology \& Tourism, 10(4), 267-281.

De Carlos, P., Araujo, N., \& Fraiz, J. (2015). The New Intermediaries of Tourist Distribution: Analysis of Online Accomodation Booking Sites. The International Journal of Management Science and Information Technology, 25, 39-58.

Đukić, V., \& Todorović, M. (2008). Kulturni turizam- most između kulturne i turističke politike, Zbornik Fakulteta dramskih umetnosti, 13-14, 112-129.

Dumont, E., Ruelle, C., \& Teller, G. (2007). Pro-active management of The Impact of Cultural Tourism Upon Urban Resources and Economies, Integrating and strengthening the European Research Area Activity, 6th Framework Programme of Research. Cordis.

Eskelsen, G., Marcus, A., \& Ferree, W. (2009). The Digital Economy Fact Book. The Progress \& Freedom Foundation.

Fotis, J., Buhalis, D., \& Rossides, N. (2012). Social Media Use and Impact during the Holiday Travel Planning Process. Information and Communication Technologies in Tourism, 10, 13-24. https://doi.org/10.1007/978-3-7091-1142$0 \_2$

Harragan. P., Evers., U., Miles. M., \& Daly, T. (2017). Customer engagement with tourism social media brands. Tourism Management, 59, 597-609. https://doi.org/10.1016/j.tourman.2016.09.015

Hsu, F. M., Lin, Y. T., \& Ho, T. K. (2012). Design and implementation of an intelligent recommendation system for tourist attractions: The integration of EBM model, bayesian network and google maps. Expert Systems with Applications, 39(3), 3257-3264. https://doi.org/10.1016/j.eswa.2011.09.013

Jiao, Y.B., Gao, J, \& Yang, J. (2013). Factors influencing consumers' adoption of social media- a theoretical model and its empirical research. Journal of Shanxi Finance Economics, 35, 43-55.

Kardes, F. R., Cline, T. W., \& Cronley, M. L. (2011). Consumer behaviour: Science and practice. South-Western.

Kim, J., \& Connolly, D. (2012). Hospitality in the age of customer empowerment. First Annual Customer Engagement Technology Study. Randolph, Hospitality Technology.

Kipper, G., \& Rampolla, J. (2013). Augmented Reality: An Emerging Technologies Guide to AR, Waltham, MA, Elsevier.

Kotler, P., \& Keller, K. (2017). Marketing Management. Prentice Hall.

Law, R., Leung, R., \& Buhalis, D. (2009). Information Technology Applications in Hospitality and Tourism: A Review of Publications from 2005 to 2007, Journal of Travel \& Tourism Marketing, 26(5), 599-623. https://doi.org/10.1080/10548400903163160 
Leask, A. (2010). Progress in visitor attraction research: Towards more effective management. Tourism Management, 31(2), 155-166. https://doi.org/10.1016/j.tourman.2009.09.004

Li, X., \& Wang, Y. (2011). China in the eyes of Western travelers as represented in travel blogs. Journal of Travel \& Tourism Marketing, 28(7), 689-719. https://doi.org/10.1080/10548408.2011.615245

Liu, Z., \& Park. S. (2015). What makes a useful online review? Implication for travel product websites. Tourism Management, 47, 140-151. https://doi.org/10.1016/j.tourman.2014.09.020

Mamaghani, F. (2009). Impact of E-Commerce on Travel and Tourism: An Historical analysis. International Journal of Management, 26, 365-386.

Milano, R., Baggio, R., \& Piatelli, B. (2011). The effects of online social media on tourism websites, 18th International conference on information technology and travel \& tourism. Inssbruk, Austria. https://doi.org/10.1007/978-3-7091-0503$0 \_38$

Munar, A. M., \& Steen Jacobsen, J. K. (2014). Motivations for sharing tourism experiences through social media. Tourism Management, 43, 46-54. https://doi.org/10.1016/j.tourman.2014.01.012

Munsters, W. (2004). Culture \& Tourism: merely a marriage of convenience?, Inaugural speech un the Centre of Expertise of Cultural Tourism, Zuyd University of Applied Sciences, Maastricht.

Pantano, E., \& Di Pietro, L. (2013). From e-tourism to f-tourism: Emerging issues from negative tourists' online reviews. Journal of Hospitality and Tourism Technology, 4(3), 211-217. https://doi.org/10.1108/JHTT-02-2013-0005

Pantano, E., Priporas, C.V., \& Stylos, N. (2017). You will like it!' using open data to predict tourists' response to a tourist attraction. Tourism Management, 60, 430438. https://doi.org/10.1016/j.tourman.2016.12.020

Park, S., Nicolau, J. L., \& Fesenmaier, D. R. (2013). Assessing advertising in a hierarchical decision model. Annals of Tourism Research, 40, 260-282. https://doi.org/10.1016/j.annals.2012.09.009

Perić, G., Jevtović, A., \& Gašić, M. (2020). Potencijali razvoja kulturnog turizma na prostoru Topličkog okruga. U B. Sančanin, \& B. Ratković-Njegovan. (ur.), Zbornik radova Naučno-stručne konferencije. Uticaj digitalnih i tradicionalnih medija na promociju i razvoj održive baštine. Sremski Krlovci. (str. 75-91). Centar za kulturu, edukaciju i medije Akademac.

Pirolli, B. (2016). Travel information online: navigating correspondents, consensus, and conversation. Current Issues in Tourism, 48, 1-7. https://doi.org/10.1080/13683500.2016.1273883

Radosavljević, Z, Ljubisavljević, T. (2020). Kombinovanje tradicionalnih i digitalnih medija u svrhu bolje prezentacije kulturnog turizma u Srbiji. U B. Sančanin, \& B. Ratković-Njegovan. (ur.), Zbornik radova Naučno-stručne konferencije. Uticaj digitalnih i tradicionalnih medija na promociju i razvoj održive baštine. Sremski Krlovci. (str. 158-168). Centar za kulturu, edukaciju i medije Akademac.

Richards, G. (1999). European cultural tourism: patterns and prospects, in: Dodd, D., Van Hemel, A.-M. (Eds). Planning European Cultural Tourism, Boekman Foundation, Amsterdam, 16-32. 
Richards, G. (2005). Cultural Tourism in Europe, CAB International, Wallington, UK.

Rodriguez Vazquez, C., Rodriguez Campo, L., Martinez Fernandes, V., \& Rodriguez Fernandez, M. (2015). The Effects of the Application of the Internet and Information and Communication Technologies in the Field of Tourism Mediation. The International Journal of Management Science and Information Technology, 27, 1-20.

Romolini, A., Fissi, S., \& Gori, E. (2020). Visitors engagement and social media in museums: evidence from Italy. International Journal of Digital Culture and Electronic Tourism, 3(1), 36-53. https://doi.org/10.1504/IJDCET.2020.10027412

Russo, A. P. (2002). Cultural Clusters and Tourism Development: the Challenge of Venice, Culture: A Driving Force for Urban Tourism, Institute for International Relation, Zagreb.

Sančanin, B., \& Dramićanin, S. (2019). The significance of the Representative List of the Intangible Cultural Heritage for the preservation of Serbian cultural heritage. Baština. 49, 419-431. https://doi.org/10.5937/bastina1949419S

Sančanin, B., Perić, G., \& Stojiljković, M. (2019). Cultural-historical resources as initiators of tourism development in Sremski Karlovci. Hotel and Tourism Management, 7(2), 77-85. https://doi.org/10.5937/menhottur1902077S

Sigala, M., Evangelos, C., \& Gretzel, U. (2010). Social media in Travel, Tourism and Hospitality: Theory, Practices and Cases, Surrey, Ashgate Publishing.

Smith, M. K., MacLeod, N., \& Hart Robertson, M. (2010). Key Concepts in Tourist Studies. Sage.

Smithson, S., Devece, C.A., \& Lapiedra, R. (2011). Online visibility as a source of competitive advantage for small and medium-sized tourism accommodation enterprises. Service Industries Journal, 31(10), 1573-1587. https://doi.org/10.1080/02642069.2010.485640

Sparks. A.B., \& Browning, V. (2011). The impact of online reviews on hotel booking intentions and perception of trust. Tourism Management, 32(6), 1310-1323. https://doi.org/10.1016/j.tourman.2010.12.011

Terrelongé, R. (2011). An Easy Guide to Search Engine Optimisation (SEO) \& Branding For Quick Results, Longe Distribution Inc.

Thao, H., \& Swierczek, F. (2008). Internet use, customer relationships and loyalty in the Vietnamese travel industry. Asia Pacific Journal of Marketing and Logistics, 20(2), 190-210.https://doi.org/10.1108/13555850810864551

Tierney, P. (2000). Internet-based evaluation of tourism web site effectiveness: Methodological issues and survey results. Journal of Travel Research, 39(2), 212-219. https://doi.org/10.1177/004728750003900211

Torres, R. (2017). Technology Trends \& the Future of Travel. Travel \& Tourism global impact \& issues, 1-17.

Tung, T., Jai, T. M., \& Davis Burns, L. (2014). Attributes of apparel tablet catalogs: Value proposition comparisons. Journal of Fashion Marketing and Management, 18(3), 321-337.https://doi.org/10.1108/JFMM-12-2012-0073

Turban, E., King, D., Lee, J. K., Liang, T. P., \& Turban, D. C. (2015). Social commerce: Foundations, social marketing, and advertising. In: Electronic commerce: A managerial and social networks perspective (pp. 309-365) Springer International Publishing. 
Turner, J. (2012). How to use Social Media Monitoring Tools. Pearson's Education Ltd.

Valdez, R. (2012). The Role of Hypertext in Consumer Decision Making: The Case of Travel Destination Choice. Journal of Entrepreneurship, Management and Innovation. 8(3), 78-95. https://doi.org/10.7341/2012835

Volo, S. (2010). Bloggers' reported tourist experiences: Their utility as a tourism data source and their effect on prospective tourists. Journal of Vacation Marketing, 16(4), 297-311. https://doi.org/10.1177/1356766710380884

Woodside, A., \& Lysonski, S. (1989). A General Model Of Traveler Destination Choice. Journal of Travel Research, 27, 8-14. https://doi.org/10.1177/004728758902700402

WTO (2019). Tourism and Culture, https://www.unwto.org/tourism-and-culture

Wu, C. T., Liu, S. C., Chu, C. F., Chu, Y. P., \& Yu, S. S., (2014). A study of open data for E. Pantano et al., Tourism Management, 60, 430-438.

Xiang, Z., Du, Q., Ma, Y., \& Fan, W. (2017). A comparative analysis of major online review platforms: Implications for social media analytics in hospitality and tourism. Tourism Management, 58, 51-65. https://doi.org/10.1016/j.tourman.2016.10.001

Xiang, Z., \& Ulrike, G. (2010). Role of social media in online travel information search. Tourism Management, $\quad 31(2), \quad$ 179-188. https://doi.org/10.1016/j.tourman.2009.02.016

Xiaolong, H., Xiaomei, Z., \& Fangyan, L. (2016). Study on the cooperation of hotels and online self-service travel business based on information technology. Revista Iberica de Sistemas e Tecnologias de Informaticao, 125-136.

Yoo, W., Lee, Y., \& Park, J. (2010). The role of interactivity in e-tailing: Creating value and increasing satisfaction. Journal of Retailing and Consumer Services, 17(2), 89-96. https://doi.org/10.1016/j.jretconser.2009.10.003

$\mathrm{Yu}, \mathrm{T} . \mathrm{T}$. (2013). Innovation of marketing communication strategy based on social media reputation. Journalism Quarterly, 3, 115-120.

Yue, G., Barnes, S. J., \& Qiong, J. (2017). Mining meaning from online ratings and reviews: tourist satisfaction analysis using latent dirichlet allocation. Tourism Management, 59(3), 467-483. https://doi.org/10.1016/j.tourman.2016.09.009

Živković, R., \& Brdar, I. (2018). Ponašanje i zaštita potrošača u turizmu. Singidunum. 
Appendix 1. Questionnaire

\begin{tabular}{|c|c|c|}
\hline 1 & $\begin{array}{l}\text { Tourists' decision of } \\
\text { travel destination }\end{array}$ & $\begin{array}{l}\text { I am always looking for information about cultural tourism } \\
\text { on the Internet } \\
\text { Internet content is the first source of information when I } \\
\text { search about cultural tourism } \\
\text { I think that using internet content to share and exchange } \\
\text { information about cultural tourism is useful } \\
\text { I will continue to use internet content to find information } \\
\text { about cultural tourism }\end{array}$ \\
\hline 2 & Participation & $\begin{array}{l}\text { I actively participate in sharing various internet content } \\
\text { related to cultural tourism } \\
\text { I can't imagine spending the day without using the internet } \\
\text { to search for cultural tourism information } \\
\text { I accept the invitation of friends to exchange information } \\
\text { and interesting things via the Internet about cultural } \\
\text { tourism }\end{array}$ \\
\hline 3 & Interactivity & $\begin{array}{l}\text { I like to use the internet to communicate with people about } \\
\text { cultural tourism } \\
\text { I use the internet very often and make many contacts } \\
\text { related to cultural tourism } \\
\text { I am satisfied with the high interactivity of internet content } \\
\text { on the topic of cultural tourism }\end{array}$ \\
\hline 4 & Divisibility & $\begin{array}{l}\text { I use internet content to share my feelings and experiences } \\
\text { related to cultural tourism } \\
\text { Most people use internet content to share experiences and } \\
\text { adventures related to cultural tourism } \\
\text { I want to use internet content to share information anytime, } \\
\text { anywhere }\end{array}$ \\
\hline 5 & Connectivity & $\begin{array}{l}\text { Internet content allows me to access a wide range of } \\
\text { information on cultural tourism } \\
\text { It is possible to find people who like the same things related } \\
\text { to cultural tourism via the Internet } \\
\text { I can be linked to the most relevant information on cultural } \\
\text { tourism via the Internet }\end{array}$ \\
\hline 6 & Quality & $\begin{array}{l}\text { If the internet content about cultural tourism is good, I am } \\
\text { ready to take time to study the information } \\
\text { I am more willing to visit internet content about cultural } \\
\text { tourism, if it has good quality } \\
\text { If internet content about cultural tourism is good, I am } \\
\text { ready to recommend it to my friends }\end{array}$ \\
\hline 7 & Convenience & $\begin{array}{l}\text { The facilitating of using internet content related to cultural } \\
\text { tourism increases my use } \\
\text { Easier access to cultural tourism information increases my } \\
\text { number of internet content visits } \\
\text { The possibility of 24-hour access to cultural tourism } \\
\text { information increases my use of Internet content }\end{array}$ \\
\hline 8 & $\begin{array}{l}\text { Information } \\
\text { transparency }\end{array}$ & $\begin{array}{l}\text { Cultural tourism information is transparent on the Internet } \\
\text { The reason why I use internet content is the availability of } \\
\text { cultural tourism information } \\
\text { The greater the transparency of cultural tourism } \\
\text { information, the more I use Internet content }\end{array}$ \\
\hline
\end{tabular}




\begin{tabular}{ll}
\hline & $\begin{array}{l}\text { When I get relevant information about cultural tourism } \\
\text { based on internet content, it increases my understanding of } \\
\text { the destination's cultural tourism product } \\
\text { It can save a lot of time using internet content related to } \\
\text { cultural tourism }\end{array}$ \\
9 Information & $\begin{array}{l}\text { It can save a lot of money, time and energy and speed up } \\
\text { the process of deciding on a travel destination, using } \\
\text { internet content related to cultural tourism } \\
\text { I think that the situation related to cultural tourism is } \\
\text { largely in line with the information presented by the } \\
\text { Internet content }\end{array}$ \\
\hline
\end{tabular}

Source: Cao, Q., Yu, B., Tian, T. X. X., 2017. The Effect of Social Media on Tourism Consumer Adoption Intention: Evidence from Urumqi. Journal of Accounting \& Marketing, 6(1), pp. 219-229.

Rad je primljen: 17.11.2020; Prihvaćen: 17.12.2020.

Received: 17 November, 2020; Accepted: 17 December, 2020 
